\title{
The first synthesis of $( \pm)$-secocuparenal, a sesquiterpene isolated from the liverwort Jungermannia infusca
}

\author{
A. Srikrishna,* L. Shaktikumar, and G. Satyanarayana \\ Department of Organic Chemistry, Indian Institute of Science, Bangalore 560 012, India \\ E-Mail: ask@orgchem.iisc.ernet.in
}

(received 25 Nov 03; accepted 10 Feb 04; published on the web 28 Feb 04)

\begin{abstract}
The first total synthesis of the sesquiterpene $( \pm)$-secocuparenal 1 isolated from the Japanese liverwort Jungermannia infusca, has been accomplished starting from the readily available $\beta$ ionone 4.
\end{abstract}

Keywords: Sesquiterpenes, secocuparenal synthesis

\section{Introduction}

Liverworts are small plants, and are rich source of unique natural products, 2 which are not found in higher plants. The Japanese and Taiwanese collections of the species Jungermannia infusca have yielded a variety of diterpenoids, sesquiterpenoids and aromatic compounds. Recently, Nagashima and coworkers reported isolation of secocuparenal 1 along with eight known di- and sesquiterpenoids from the Jungermannia infusca sample collected at Awajishima.3 Secocuparenal 1 is the $\mathrm{C}_{2}-\mathrm{C}_{3}$ secologue of the aromatic sesquiterpene cuparene 2. Structure of secocuparenal 1 has been established on the basis of detailed NMR spectral studies $\left({ }^{1} \mathrm{H},{ }^{13} \mathrm{C}\right.$, DEPT, ${ }^{1} \mathrm{H}^{-1} \mathrm{H}$ COSY, phase sensitive NOESY, HMQC and HMBC). Difficulty associated with the creation of two vicinal quaternary carbon atoms in a cyclopentane framework made cuparenoid and herbertene sesquiterpenes challenging synthetic targets. Herein we wish to report the first total synthesis4 of $( \pm)$-secocuparenal 1 starting from the readily and abundantly available $\beta$-ionone 4. 


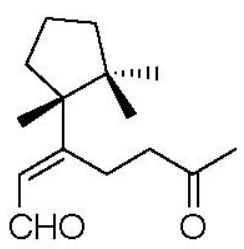

1

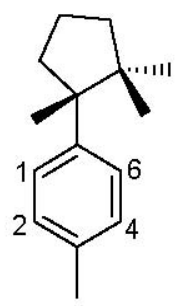

2

Retrosynthetic analysis, Scheme 1, revealed that the dione 3 as a possible precursor for the synthesis of secocuparenal 1. Synthesis of the dione $\mathbf{3}$ starting from $\beta$-ionone $\mathbf{4}$ has been already developed 5 by employing a Lewis acid catalysed ring contraction of the epoxide 5 .

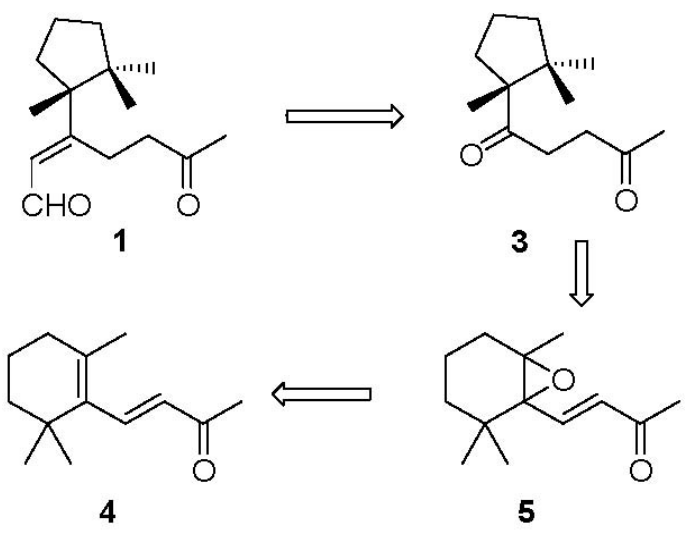

\section{Scheme 1}

The synthetic sequence starting from $\beta$-ionone $\mathbf{4}$ is depicted in Scheme 2. Thus, chemoselective epoxidation of the cyclohexene double bond of $\beta$-ionone 4 with one equivalent of $m$-chloroperbenzoic acid (MCPBA) generated the epoxide 5 in a highly regioselective manner. ${ }^{6}$ Treatment of the epoxide 5 with boron trifluoride etherate in methylene chloride at low temperature furnished the enedione 6 , which on hydrogenation in ethanol using $5 \%$ palladium over charcoal as the catalyst furnished the dione $3 .^{5}$ It is worth mentioning that the synthesis of 1,1,2,2-tetrasubstituted cyclopentane, e.g. the diones $\mathbf{3}$ and $\mathbf{6}$, by this strategy has been exploited in the synthesis of several sesquiterpenes such as cuparene, herbertene, 6-herbertenol, cyclocuparenol, microbiotene, microbiotol etc. ${ }^{5}$ It was obvious that for addition of a two carbon chain to the sterically crowded ketone in the dione 3, sterically less crowded C-4 ketone in the pentanedione 3 needs to be protected. However, attempted ketalisation of the unhindered ketone in the dione 3 under standard conditions was unsuccessful and generated only the furan 7 , whose structure was deduced from its spectral data in particular the ${ }^{1} \mathrm{H}$ and ${ }^{13} \mathrm{C}$ NMR analysis. Formation of the furan derivative 7 could be readily explained on the basis of acid catalyzed cyclisation of the 1,4-diketone moiety in the dione 3 . Consequently, it was contemplated to reduce the unhindered ketone in the dione 3 to the corresponding secondary alcohol and protect 
it as its THP ether. Thus, controlled reduction of the dione 3 with sodium borohydride in methanol furnished a 1:1 epimeric mixture of the hydroxyketone $\mathbf{8}$, which was found to be inseparable, whose structure as well as the epimeric nature was evident from its spectral data. Since the isomers will converge to a ketone at a later stage, the sequence was carried out on the mixture of the diasteromers of the hydroxyketone 8 . Treatment of a mixture of the hydroxyketone $\mathbf{8}$ with dihydrofuran and a catalytic amount of pyridinium $p$-toluenesulfonate (PPTS) furnished a diastereomeric mixture of the ketoether 9. The ${ }^{13} \mathrm{C} \mathrm{NMR}$ spectrum of the ketoether 9 indicated, as expected, approximately equal ratio of four stereoisomers. As the simple Wittig reaction as well as its other variants were unsuccessful to add the required two carbon chain on the ketone of the ketoether 9, a Grignard reaction based methodology was explored. $^{7}$ Thus, reaction of the ketoether 9 with vinylmagnesium bromide furnished a diastereomeric mixture of the tertiary alcohol 10, which on deprotection with PPTS in methanol furnished a diastereomeric mixture of the diol 11. Finally, simultaneous oxidation of the secondary and allylic tertiary alcohols in $\mathbf{1 1}$ with pyridinium chlorochromate (PCC) and silica gel in methylene chloride at room temperature generated, exclusively, ${ }^{8}( \pm)$-secocuparenal $\mathbf{1}$. The exclusive formation of the E-olefin in the oxidation of the allyl alcohol in $\mathbf{1 1}$ is a consequence of the steric crowding due to the bulky 1,2,2-trimethylcyclopentyl substituent. The synthetic material 1 exhibited ${ }^{1} \mathrm{H}$ and ${ }^{13} \mathrm{C}$ NMR (in $\mathrm{C}_{6} \mathrm{D}_{6}$ ) and mass spectra identical to those of natural secocuparenal.

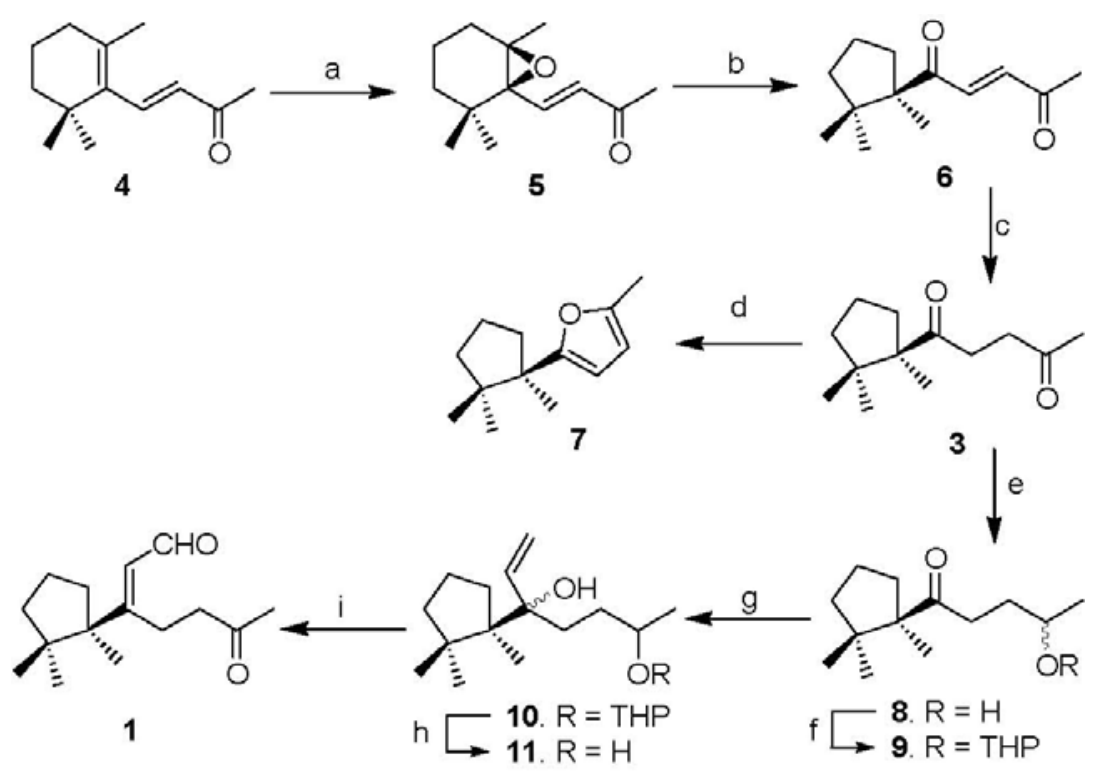

Scheme 2. Reagents, Conditions and Yields: (a) m-CPBA, $\mathrm{NaHCO}_{3}, \mathrm{CH}_{2} \mathrm{Cl}_{2}, 0^{\circ} \mathrm{C}, 3 \mathrm{~h}, 90 \%$; (b) $\mathrm{BF}_{3} . \mathrm{Et}_{2} \mathrm{O}, \mathrm{CH}_{2} \mathrm{Cl}_{2},-70{ }^{\circ} \mathrm{C}, 1 \mathrm{~h}, 94 \%$; (c) $\mathrm{H}_{2}, 5 \% \mathrm{Pd} / \mathrm{C}$, EtOH, 12 h, 100\%; (d) $\left(\mathrm{CH}_{2} \mathrm{OH}\right) 2, p-$ TSA, ${ }_{6} \mathrm{H}_{6}$, reflux, 2 h, 78\%; (e) $\mathrm{NaBH}_{4}, \mathrm{MeOH}, 0{ }^{\circ} \mathrm{C}, 10$ min., 93\%; (f) DHP, $\mathrm{CH}_{2} \mathrm{Cl}_{2}$, PPTS, 1 h, 91\%; (g) $\mathrm{CH}_{2}=\mathrm{CHMgBr}$, THF, 3 h; (h) DHP, MeOH, PPTS, 4 h; (i) PCC, silica gel, $\mathrm{CH}_{2} \mathrm{Cl}_{2}, 2$ h; overall $25 \%$ for 3 steps (from 9 ). 
In conclusion, we have accomplished the first total synthesis of $( \pm)$-secocuparenal $\mathbf{1}$ isolated from the Japanese liverwort Jungermannia infusca. Currently, we are investigating the extension of the methodology for the enantioselective synthesis.

\section{Experimental Section}

General Procedures. IR spectra were recorded on Jasco FTIR 410 spectrophotometer. ${ }^{1} \mathrm{H}(300$ $\mathrm{MHz})$ and ${ }^{13} \mathrm{C}(75 \mathrm{MHz}) \mathrm{NMR}$ Spectra were recorded on Jeol $\lambda$-300 spectrometer. $\beta$-Ionone was obtained from M/s Kelkar and Company. Vinyl bromide was freshly prepared by base catalysed dehydrobromination of 1,2-dibromoethane. Acme's silica gel (100-200 mesh) was used for column chromatography. Low temperature reactions were conducted in a bath made of sodium chloride and ice, or ethyl alcohol and liquid nitrogen.

2-(1,2,2-Trimethylcyclopentyl)-5-methylfuran (7). To a magnetically stirred solution of the dione $^{5} 3(50 \mathrm{mg}, 0.238 \mathrm{mmol})$ in $5 \mathrm{ml}$ of benzene, were added ethylene glycol $(1 \mathrm{ml})$ and a catalytic amount of $p$-toluenesulphonic acid (PTSA) and the solution was refluxed using a DeanStark water separator for $2 \mathrm{~h}$. The reaction mixture was cooled, washed with aq. sodium bicarbonate and brine, and dried $\left(\mathrm{Na}_{2} \mathrm{SO}_{4}\right)$. Evaporation of the solvent and purification of the residue on a silica gel column using ethyl acetate-hexane (1:5) as eluent furnished the furan derivative 7 (38 mg, 78\%) as oil. IR (neat): $v_{\max } / \mathrm{cm}^{-1} 1613,1557 .{ }^{1} \mathrm{H} \mathrm{NMR}\left(300 \mathrm{MHz}, \mathrm{CDCl}_{3}+\right.$ $\left.\mathrm{CCl}_{4}\right): \delta 5.80$ and $5.70(2 \mathrm{H}, 2 \mathrm{x} \mathrm{d}, J=3.3 \mathrm{~Hz}), 2.24\left(3 \mathrm{H}, \mathrm{s}, \mathrm{Ar}-\mathrm{CH}_{3}\right), 2.35-2.15(1 \mathrm{H}, \mathrm{m}), 1.82-$ $1.50(5 \mathrm{H}, \mathrm{m}), 1.19(3 \mathrm{H}, \mathrm{s}), 1.02(3 \mathrm{H}, \mathrm{s})$ and $0.64(3 \mathrm{H}, \mathrm{s})\left[3 \mathrm{x} \operatorname{tert}-\mathrm{CH}_{3}\right) .{ }^{13} \mathrm{C} \mathrm{NMR}(75 \mathrm{MHz}$, $\left.\mathrm{CDCl}_{3}+\mathrm{CCl}_{4}\right): \delta 160.0(\mathrm{C}, \mathrm{C}-2), 149.3(\mathrm{C}, \mathrm{C}-5), 105.4(\mathrm{CH}), 104.8(\mathrm{CH}), 48.3\left(\mathrm{C}, \mathrm{C}-1^{\prime}\right), 44.7$ (C, C-2'), $39.5\left(\mathrm{CH}_{2}\right), 36.2\left(\mathrm{CH}_{2}\right), 26.1\left(\mathrm{CH}_{3}\right), 24.2\left(\mathrm{CH}_{3}\right), 22.3\left(\mathrm{CH}_{3}\right), 20.0\left(\mathrm{CH}_{2}, \mathrm{C}-4{ }^{\prime}\right), 13.7$ $\left(\mathrm{CH}_{3}\right)$. Mass: m/z $192(\mathrm{M}+, 8 \%), 177(16), 161$ (18), 149 (20), 142 (22), 135 (30), 122 (30), 121 (27), 111 (30), 109 (28).

1-(1,2,2-Trimethylcyclopentyl)-4-hydroxypentan-1-one (8). Sodium borohydride (18 mg, 0.48 mmol) was added to a cold $\left(0{ }^{\circ} \mathrm{C}\right)$ magnetically stirred solution of the diones $3(300 \mathrm{mg}, 1.43$ $\mathrm{mmol})$ in dry methanol $(2 \mathrm{ml})$ and stirred for $10 \mathrm{~min}$. at the same temperature. The solvent was removed under reduced pressure. The residue was taken in ether and washed with brine and dried over $\left(\mathrm{Na}_{2} \mathrm{SO}_{4}\right)$. Evaporation of the solvent and purification of the residue over a silica gel column using ethyl acetate-hexane (1:20) as eluent furnished a 1:1 epimeric mixture of the hydroxy ketone 8 (281 mg, 93\%) as an oil. IR (neat): $v_{\max } / \mathrm{cm}^{-1} 3427,1695 .{ }^{1} \mathrm{H} \mathrm{NMR}\left(300 \mathrm{MHz}, \mathrm{CDCl}_{3}+\right.$ $\mathrm{CCl}_{4}, 1: 1$ mixture of epimers): $\delta 3.80-3.65(1 \mathrm{H}, \mathrm{m}, \mathrm{CHOH}), 2.70-2.50(2 \mathrm{H}, \mathrm{m}), 2.48-2.35(1 \mathrm{H}$, m), 2.09 (1 H, br s), 1.80-1.40 (6 H, m), 1.17 (3 H, d, J = 6.3 Hz, sec-CH3), 1.13 (3 H, s), 1.08 (3 $\mathrm{H}, \mathrm{s})$ and $0.84(3 \mathrm{H}, \mathrm{s})\left[3 \mathrm{x}\right.$ tert- $\left.\mathrm{CH}_{3}\right] .{ }^{13} \mathrm{C} \mathrm{NMR}\left(75 \mathrm{MHz}, \mathrm{CDCl}_{3}+\mathrm{CCl}_{4}, 1: 1\right.$ mixture of epimers): $\delta 215.6(\mathrm{C}, \mathrm{C}=\mathrm{O}), 67.3(\mathrm{CH}, \mathrm{C}-4), 59.6\left(\mathrm{C}, \mathrm{C}-1^{\prime}\right), 44.3(\mathrm{C}, \mathrm{C}-2$ ') $), 40.3\left(\mathrm{CH}_{2}\right), 36.9$ and $36.7\left(\mathrm{CH}_{2}\right), 34.7\left(\mathrm{CH}_{2}\right), 32.9$ and $32.8\left(\mathrm{CH}_{2}\right), 25.7\left(\mathrm{CH}_{3}\right), 24.6\left(\mathrm{CH}_{3}\right), 24.2$ and $24.1\left(\mathrm{CH}_{3}\right), 21.1$ 
and $21.0\left(\mathrm{CH}_{3}\right), 19.8\left(\mathrm{CH}_{2}, \mathrm{C}-4^{\prime}\right)$. Mass: m/z $194\left(\mathrm{M}-\mathrm{H}_{2} \mathrm{O}, 1 \%\right), 125$ (25), 111 (60), 101 (25), 95 (23), 69 (100). HRMS: m/z Calcd. for $\mathrm{C}_{13} \mathrm{H}_{24} \mathrm{O}_{2} \mathrm{Na}(\mathrm{M}+\mathrm{Na}): 235.1674$. Found: 235.1682.

1-(1,2,2-Trimethylcyclopentyl)-4-(2-tetrahydropyranyloxy)pentan-1-one (9). Dihydropyran $(0.25 \mathrm{ml}, 2.54 \mathrm{mmol})$ and a catalytic amount of PPTS were added to a magnetically stirred solution of the hydroxy ketone $8(280 \mathrm{mg}, 1.32 \mathrm{mmol})$ in methylene chloride $(1 \mathrm{ml})$ and stirred for $1.5 \mathrm{~h}$ at RT. The reaction mixture was then diluted with water and extracted with methylene chloride ( $3 \times 5 \mathrm{ml})$. The extract was washed with brine and dried ( $\left.\mathrm{Na}_{2} \mathrm{SO}_{4}\right)$. Evaporation of the solvent and purification of the residue over a silica gel column using ethyl acetate-hexane (1:5) as eluent furnished a diastereomeric mixture of the keto THP ether 9 (356 mg, 91\%) as oil. IR (neat): $v_{\max } / \mathrm{cm}_{-1} 1697,1062 .{ }^{1} \mathrm{H} \mathrm{NMR}\left(300 \mathrm{MHz}, \mathrm{CDCl}_{3}+\mathrm{CCl}_{4}\right.$, mixture of 4 isomers): $\delta 4.92$ and 4.59 (1 H, s, O-CH-O), 3.95-3.65 (2 H, m, OCH2), 3.55-3.40 (1 H, m, OCH), 2.70-2.45 (2 H, $\mathrm{m}), 1.95-1.40(14 \mathrm{H}, \mathrm{m}), 1.22$ and $1.01\left(3 \mathrm{H}, \mathrm{d}, J=6.3 \mathrm{~Hz}, \mathrm{sec}-\mathrm{CH}_{3}\right), 1.12(3 \mathrm{H}, \mathrm{s}), 1.08$ and 1.07 $(3 \mathrm{H}, \mathrm{m}), 0.84$ and $0.83(3 \mathrm{H}, \mathrm{s}) .{ }^{13} \mathrm{C} \mathrm{NMR}\left(75 \mathrm{MHz}, \mathrm{CDCl}_{3}+\mathrm{CCl}_{4}\right.$, mixture of 4 isomers): $\delta$ 214.6 and 214.2 (C, $\mathrm{C}=\mathrm{O}), 98.4,98.3$, 95.8, $94.0(\mathrm{CH}, \mathrm{O}-\mathrm{CH}-\mathrm{O}), 73.1,73.0,70.6$ and $70.5(\mathrm{CH}$, $\mathrm{O}-\mathrm{CH}), 62.5$ and $62.3\left(\mathrm{CH}_{2}, \mathrm{OCH}_{2}\right), 59.4$ and $59.3(\mathrm{C}), 44.0(\mathrm{C}), 40.1\left(\mathrm{CH}_{2}\right), 36.4,36.2$ and 35.5 $\left(\mathrm{CH}_{2}\right), 34.6$ and $34.5\left(\mathrm{CH}_{2}\right), 31.2$ and $31.1\left(\mathrm{CH}_{2}\right), 31.0,30.5,30.1$ and $30.0\left(\mathrm{CH}_{2}\right), 25.6$ and 25.8 $\left(\mathrm{CH}_{3}\right), 25.5\left(\mathrm{CH}_{2}\right), 24.4\left(\mathrm{CH}_{3}\right), 21.5$ and $19.6\left(\mathrm{CH}_{3}\right), 20.9\left(\mathrm{CH}_{3}\right), 20.0$ and $19.8\left(\mathrm{CH}_{2}\right), 19.6$ (CH2). Mass: m/z 211 (M-THP, 30\%), 195 (25), 175 (20), 125 (29), 111 (50), 99 (30), 95 (30). HRMS: m/z Calcd. for $\mathrm{C}_{18} \mathrm{H}_{32} \mathrm{O}_{3} \mathrm{Na}(\mathrm{M}+\mathrm{Na}): 319.2249$. Found: 319.2265.

trans-3-(1,2,2-Trimethylcyclopentyl)-6-oxohept-2-enal (secocuparenal 1). A solution of the keto THP ether $9(150 \mathrm{mg}, 0.5 \mathrm{mmol})$ in $2 \mathrm{ml}$ of dry THF was added to a magnetically stirred solution of vinylmagnesium bromide [prepared from $240 \mathrm{mg}(10 \mathrm{mmol})$ of magnesium in $4 \mathrm{ml}$ of dry THF and vinyl bromide] in dry THF $(4 \mathrm{ml})$ and the reaction mixture was stirred for $2 \mathrm{~h}$ at RT. It was then cooled to $0{ }^{\circ} \mathrm{C}$ and quenched with saturated ammonium chloride solution (10 ml) and extracted with ether. The combined ether extract was washed with brine and dried $\left(\mathrm{Na}_{2} \mathrm{SO}_{4}\right)$. Evaporation of the solvent and purification of the residue on a silica gel column using ethyl acetate-hexane (1:20) as eluent furnished a diastereomeric mixture of the alcohol 10 (containing $\approx 30 \%$ of unreacted starting material 9 which was found to be unseparable) as oil. IR (neat): Hmax/cm-1: 3480 . A catalytic amount of PPTS was added to a magnetically stirred solution of the mixture of the allyl alcohol $10(140 \mathrm{mg})$, obtained above, in $2.5 \mathrm{ml}$ of dry methanol and stirred for $5 \mathrm{~h}$ at RT. The solvent was evaporated under reduced pressure; saturated ammonium chloride solution $(20 \mathrm{ml})$ was added to the residue and extracted with ether. The combined ether extract was washed with brine and dried $\left(\mathrm{Na}_{2} \mathrm{SO}_{4}\right)$. Evaporation of the solvent and purification of the residue on a silica gel column using ethyl acetate-hexane (1:20) as eluent furnished a diastereomeric mixture of the diol 11 (containing hydroxyketone $\mathbf{8}$ derived from 9) as oil. IR (neat): Hmax/cm-1: 3383, 1693. To a magnetically stirred solution of a diastereomeric mixture of the allylic alcohol $11(100 \mathrm{mg})$ in $1.5 \mathrm{ml}$ of methylene chloride was added a mixture of PCC (430 $\mathrm{mg}, 2 \mathrm{mmol}$ ) and silica gel $(430 \mathrm{mg}$ ). The reaction mixture was stirred at RT for $2 \mathrm{~h}$, filtered through a small silica gel column and eluted the column with more methylene chloride. Evaporation of the solvent and purification of the residue over a silica gel column using ethyl 
acetate-hexane (1:20) as eluent first furnished diketone 3 (25 mg, 30\%). Further elution of the column with the ethyl acetate-hexane (1:10) as eluent furnished 2,3-secocuparenal 1 (21 mg, $25 \%$ for three steps based on the dione 3 recovered). IR (neat): $v_{\max } / \mathrm{cm}^{-1} 1717,1667 .{ }^{1} \mathrm{H} \mathrm{NMR}$ (300 MHz, C6D6): $\delta 9.88(1 \mathrm{H}, \mathrm{d}, J=7.4 \mathrm{~Hz}, \mathrm{CHO}), 5.96(1 \mathrm{H}, \mathrm{d}, J=7.4 \mathrm{~Hz}$, olefinic H), 2.80$2.50(2 \mathrm{H}, \mathrm{m}), 2.10-1.95(2 \mathrm{H}, \mathrm{m}), 1.92-1.67(1 \mathrm{H}, \mathrm{m}), 1.56(3 \mathrm{H}, \mathrm{s}, \mathrm{CH} \mathrm{C}=\mathrm{O}), 1.50-1.20(5 \mathrm{H}$, $\mathrm{m}), 0.80(3 \mathrm{H}, \mathrm{s}), 0.74(3 \mathrm{H}, \mathrm{s})$ and $0.56(3 \mathrm{H}, \mathrm{s})\left[3 \mathrm{x}\right.$ tert- $\left.\mathrm{CH}_{3}\right] .{ }^{13} \mathrm{C} \mathrm{NMR}(75 \mathrm{MHz}, \mathrm{C} 6 \mathrm{D} 6): \delta$ $204.1(\mathrm{C}, \mathrm{C}=\mathrm{O}), 190.4(\mathrm{CH}, \mathrm{CHO}), 170.4(\mathrm{C}, \mathrm{C}=\mathrm{CH}), 127.6(\mathrm{CH}, \mathrm{C}=\mathrm{CH}), 53.5(\mathrm{C}), 45.4\left(\mathrm{CH}_{2}\right)$, $44.9(\mathrm{C}), 40.1\left(\mathrm{CH}_{2}\right), 35.8\left(\mathrm{CH}_{2}\right), 29.2\left(\mathrm{CH}_{3}\right), 26.5\left(\mathrm{CH}_{3}\right), 24.3\left(\mathrm{CH}_{3}\right), 24.0\left(\mathrm{CH}_{2}\right), 22.2\left(\mathrm{CH}_{3}\right)$, $19.5\left(\mathrm{CH}_{2}\right)$. Mass: m/z $218\left(\mathrm{M}-\mathrm{H}_{2} \mathrm{O}, 5 \%\right), 193$ (10), 178 (10), 175 (15), 165 (15), 149 (35), 131 (15), 121 (20), 109 (40), 107 (35), 95 (30), 43 (100).

\section{Acknowledgments}

We thank Professors Y. Asakawa and F. Nagashima for providing the copies of the NMR and mass spectra of natural secocuparenal; M/s Kelkar \& Co for the generous gift of $\beta$-ionone; Indian Academy of Sciences for a summer fellowship to LS and the Council of Scientific and Industrial Research, New Delhi for the award of a research fellowship to GS.

\section{References and Notes}

1. Indian Academy of Sciences Summer Fellow-2003. Present address: Department of Chemistry, Sri Kaliswari College, Sivakasi 626130.

2. Asakawa, Y. In Progress in the Chemistry of Organic Natural Products; Herz, W.; Kirby, G. W.; Moore, R. E.; Steglich, W.; Tamm, Ch. Eds; Springer-Verlag: Wien, New York, 1995, Vol. 65.

3. Nagashima, F.; Suzuki, M.; Asakawa, Y. Phytochemistry 2001, 56, 807.

4. To the best of our knowledge, there is no report in the literature on the synthesis of secocuparenal 1.

5. (a) Srikrishna, A.; Nagamani, S. A. J. Chem. Soc., Perkin Trans. 1 1999, 3393. See also: (b) Zhao, X. Z.; Jia, Y. X.; Tu, Y. Q. J. Chem. Res. (M) 2003, 210. (c) Abad, A.; Agullo, C.; Cunat, A. C.; Perni, R. H. J. Org. Chem. 1999, 64, 1741. (d) Ho, T. -L.; Chang, M. H. J. Chem. Soc., Perkin Trans. 1 1999, 2479 and references cited therein.

6. It is worth mentioning that presence of any additional amount of MCPBA in the reaction medium results in the generation of the Baeyer-Villiger oxidation product of 5, i.e. E-2[2,2,6-trimethyl-7-oxabicyclo[4.1.0]heptan-1-yl]ethenyl acetate.

7. (a) Srikrishna, A.; Satyanarayana, G. Tetrahedron Lett. 2003, 44, 1027. (b) Buchi, G.; Egger, B. J. Org. Chem. 1971, 36, 4379.

8. It is worth mentioning that the oxidation reaction did not produce any detectable amount of the Zisomer. 